\title{
Effectiveness of immunosuppressive therapy for nephrotic syndrome in a patient with late-onset Fabry disease: a case report and literature review
}

Hironobu Fujisawa', Yosuke Nakayama', Shoichiro Nakao², Ryo Yamamoto', Yuka Kurokawa ${ }^{1}$, Nao Nakamura', Akiko Nagata', Takahiro Tsukimura ${ }^{3}$, Tadayasu Togawa $^{3}$, Hitoshi Sakuraba ${ }^{4}$ and Kei Fukami ${ }^{1 *}$

\begin{abstract}
Background: Fabry disease (FD) is an X-linked lysosomal storage disorder caused by mutations of the GLA gene, followed by deficiency in a-galactosidase A (a-gal) activity. Nephrotic syndrome, as the renal phenotype of FD, is unusual. Here, we report the rare case of a patient with FD with nephrotic syndrome whose proteinuria disappeared by immunotherapy.

Case presentation: A 67-year-old Japanese man was admitted to our hospital because of emesis, abdominal pain, and facial edema due to nephrotic syndrome. The patient was diagnosed with focal segmental glomerulosclerosis (FSGS) by renal biopsy before being diagnosed with FD, and immunotherapy was initiated. After treatment, the kidney biopsy results showed typical glycosphingolipid accumulation in the podocytes of this patient. The white blood cell a-gal activity was very low, and genetic analysis revealed a GLA gene variant (M296l), which is known as a late-onset genetic mutation of FD. Immunotherapy (steroids and cyclosporine A) dramatically improved the massive proteinuria. Currently, he has been undergoing enzyme replacement therapy, and his proteinuria has further decreased. There is the possibility that other nephrotic syndromes, such as minimal change nephrotic syndrome or FSGS, may co-exist in this patient.
\end{abstract}

Conclusions: We experienced the rare case of a FD patient whose nephrotic syndrome disappeared by immunotherapy. These findings suggest that immunosuppressive treatment may be considered if nephrotic syndrome develops, even in patients with FD.

Keywords: Fabry disease, Late-onset variant, Nephrotic syndrome, Immunotherapy, Enzyme replacement therapy

\section{Background}

Fabry disease (FD) is a rare $\mathrm{X}$-linked lysosomal storage disorder that is caused by a deficiency of $\alpha$-galactosidase A ( $\alpha$-gal) activity, which leads to the accumulation of globotriaosylceramide (GB-3) in cells. The accumulation of GB-3 in various organs, such as the kidneys and heart, as well as the nervous system, has been speculated to be the mechanism involved in tissue damage $[1,2]$. The major conditions associated with this disease are life-

\footnotetext{
* Correspondence: fukami@med.kurume-u.ac.jp

${ }^{1}$ Division of Nephrology, Department of Medicine, Kurume University School of Medicine, 67 Asahi-machi, Kurume city, Fukuoka, Japan

Full list of author information is available at the end of the article
}

threatening complications, such as heart failure, renal failure, and cerebrovascular diseases at a young age. FD is classified into three main categories, i.e., classical variants, late-onset variants, and heterozygous variants, based on the presence or absence of characteristic symptoms, age of onset, sex, and gene mutation. The impairment of podocytes caused by GB-3 accumulation leads to the development of microalbuminuria and proteinuria as the first signs of renal functional impairment in FD [1]. However, a few FD patients with nephrotic range proteinuria have been reported, and massive proteinuria is unusual in this disease. Here, we report the rare case of a patient with late-onset FD with nephrotic syndrome,

(C) The Author(s). 2019 Open Access This article is distributed under the terms of the Creative Commons Attribution 4.0 International License (http://creativecommons.org/licenses/by/4.0/), which permits unrestricted use, distribution, and 
who achieved complete remission after immunosuppressive therapy, with a literature review.

\section{Case presentation}

A 67-year-old Japanese man was admitted to Munakata Suikokai General Hospital, Fukuoka, Japan, in December 2016 for angina and was subsequently diagnosed with atypical angina. He was treated with a Ca blocker (benidipine hydrochloride) and nitric acid without percutaneous coronary angiography. The urinary protein level before admission to the hospital was $( \pm)$ by dipstick test, and the serum albumin level was $3.7 \mathrm{~g} / \mathrm{dL}$. His leg edema was rapidly worsening before admission to the hospital. In April 2017, he presented to the Kurume University Hospital, Fukuoka, Japan, because of emesis, abdominal pain, and facial edema due to hypoalbuminemia. The patient's leg edema rapidly appeared 1 week before admission, suggesting the rapid onset of nephrotic syndrome. Typical FD findings, such as angiokeratoma, acroparesthesia, hypohidrosis, and corneal opacities, were absent. His mother had died from uterine body cancer at 50 years of age. Typical renal and heart disease or symptoms of FD in his brothers and maternal family members were not detected in family history. On examination, his blood pressure, pulse rate, height, and weight were $103 / 63 \mathrm{mmHg}, 62 \mathrm{bpm}$ (regular sinus rhythm), $167 \mathrm{~cm}$, and $63 \mathrm{~kg}$, respectively. Table 1 shows the patient's laboratory data. His serum creatinine and blood urea nitrogen levels were 1.10 and $27.4 \mathrm{mg} / \mathrm{dL}$, respectively. Urinalysis demonstrated $3+$ protein as well as oval fat bodies, wide and fat casts, and mulberry cells. His urinary protein and albumin levels were $11.13 \mathrm{~g} / \mathrm{gCr}$ and $1.63 \mathrm{~g} / \mathrm{dL}$, respectively. He was then diagnosed with nephrotic syndrome. After hospitalization, his creatinine level continued to increase to a peak of $2.7 \mathrm{mg} / \mathrm{dL}$, and his urine output decreased. Because of the rapid progression of nephrotic syndrome and renal dysfunction, oral prednisolone was immediately initiated at a dose of 1 $\mathrm{mg} / \mathrm{kg} /$ day. In addition, cyclosporine A (CyA) was prescribed at a dose of $100 \mathrm{mg} /$ day as an additional immunosuppressive therapy. The massive proteinuria dramatically improved, and his serum creatinine and albumin levels returned to baseline $(0.6 \mathrm{mg} / \mathrm{dL}$ and $4 \mathrm{~g} / \mathrm{dL}$, respectively). Percutaneous renal biopsy was performed 4 days after admission. Fifteen glomeruli were evaluated using light microscopy, and segmental sclerosis (Fig. 1a), vacuolization, and foamy changes in podocytes were observed (Fig. 1b and c). These foamy changes were also observed in the tubular epithelial cells, although to a much lesser extent than in the podocytes. These foamy cells were also found in the urine, which are known as mulberry bodies (Fig. 1d). No vascular involvement was observed. Immunohistochemistry showed no specific deposition of immunoglobulin or complement factors (data not shown). Electron microscopy revealed abundant lamellar bodies in the podocyte cytoplasm with widespread foot process fusion (Fig. 1e). These findings were compatible with renal FD. White blood cell (WBC) $\alpha$-gal activity was $1 \mathrm{nmol} / \mathrm{h} / \mathrm{mg}$ protein (normal range, 20-80 $\mathrm{nmol} / \mathrm{h} / \mathrm{mg}$ protein), and the plasma lyso-GB-3 level was $7.4 \mathrm{nmol} / \mathrm{L}$ (normal range, $0.14-0.75 \mathrm{nmol} / \mathrm{L}$ ). We performed gene analysis, and the M296I mutation was detected, which is well known as a late-onset variant of FD [3]. Over the next 12 months, prednisolone and CyA were slowly tapered, and enzyme replacement therapy (ERT) (agalsidase- $\beta, 1 \mathrm{mg} / \mathrm{kg}, 57 \mathrm{mg}$ every 2 weeks) was initiated intravenously. His proteinuria became undetectable, and he showed sustained nephrotic syndrome remission $(0.15 \mathrm{~g} / \mathrm{gCr})$ (Fig. 2). There were no adverse events related to immunotherapy or ERT during the follow-up period.

\section{Discussion and conclusion}

Patients with FD usually show less proteinuria, at approximately $1 \mathrm{~g} /$ day or less, despite the accumulation of GB-3 in podocytes. Although $7.3 \%$ of male FD patients have been reported to have nephrotic-range proteinuria [4], only a few male cases of FD with nephrotic syndrome have been reported to date (Table 2). Zarate et al. reported the case of a patient with a nonsense FD mutation (W226X) with nephrotic syndrome developing secondary to minimal change disease [11]. Oral prednisolone at a dose of 2 $\mathrm{mg} / \mathrm{kg} /$ day divided into two doses significantly improved his proteinuria to $100 \mathrm{mg} / \mathrm{dL}$ [11]. This team concluded that other causes of renal pathology must be considered because patients may respond to immunotherapy. Indeed, several glomerular diseases can coexist with FD, including IgA nephropathy, membranous GN, lupus nephritis, and crescentic GN, including ANCA-positive renal disease [6, 13-15]. Further, it should be noted that the rarity of proteinuria $>1 \mathrm{~g} /$ day in Fabry nephropathy in women should strongly suggest the presence of an alternate diagnosis. In our case, treatment with prednisolone led to remission of the heavy proteinuria. Renal pathology showed focal segmental glomerulosclerosis (FSGS), which could suggest the coexistence with FD. However, since prednisolone rapidly reduced the massive proteinuria regardless of the low selectivity index, minimal change nephrotic syndrome might not be excluded. Although we did not perform whole-exome sequencing analysis, it would be interesting to test for genes related to FSGS, although the strike rate is expected to be low in steroid-sensitive nephrotic syndrome in adults. The other mechanisms by which immunosuppressive drugs improve nephrotic syndrome in patients with FD are likely related to the inhibition of FDassociated inflammation and immune responses caused by GB-3. FD has been reported to lead a proinflammatory profile in cells, including podocytes, and immune 
Table 1 Laboratory characteristics of the patient

\begin{tabular}{|c|c|c|}
\hline Valuables & & (normal range \\
\hline \multicolumn{3}{|l|}{ (Urinalysis) } \\
\hline uPCR $(\mathrm{g} / \mathrm{gCr})$ & 11.13 & $(<0.15)$ \\
\hline Selectivity Index & 0.262 & \\
\hline Hematuria & $2+$ & \\
\hline \multicolumn{3}{|l|}{ Urine sediments } \\
\hline Oval fat body & + & \\
\hline Wide cast & + & \\
\hline Waxy cast & + & \\
\hline Fat cast & + & \\
\hline Epithelial cast & + & \\
\hline Mulberry cells & + & \\
\hline \multicolumn{3}{|l|}{ (Biochemical examination) } \\
\hline WBC $(/ \mu l)$ & 6800 & $(3300-8600)$ \\
\hline Neutrophil (\%) & 79.4 & $(40.0-71.9)$ \\
\hline Eosinophil (\%) & 2.9 & $(0.0-5.0)$ \\
\hline Basophil (\%) & 0.7 & $(0.0-1.0)$ \\
\hline Lymphocyte (\%) & 11.4 & $(26.0-46.6)$ \\
\hline Monocyte (\%) & 5.6 & $(2.3-7.7)$ \\
\hline Red blood cell $\left(10^{4} / \mu l\right)$ & 496 & $(435-555)$ \\
\hline Hemoglobin (g/dl) & 14.9 & $(13.7-16.8)$ \\
\hline Hematocrit (\%) & 45.3 & $(40.7-50.1)$ \\
\hline Platelet $\left(10^{4} / \mu \mathrm{l}\right)$ & 42.1 & $(15.8-34.8)$ \\
\hline AST(U/I) & 33 & $(13-30)$ \\
\hline $\mathrm{ALT}(\mathrm{U} / \mathrm{l})$ & 15 & $(10-30)$ \\
\hline Total protein $(\mathrm{g} / \mathrm{dl})$ & 4.87 & $(6.6-8.1)$ \\
\hline Serum albumin (g/dl) & 1.63 & $(4.1-5.1)$ \\
\hline Blood urea nitrogen (mg/dl) & 27.4 & $(8-20)$ \\
\hline Creatinine (mg/dl) & 1.10 & $(0.65-1.07)$ \\
\hline $\operatorname{eGFR}\left(\mathrm{ml} / \mathrm{min} / 1.73 \mathrm{~m}^{2}\right)$ & 52.3 & \\
\hline $\mathrm{Na}(\mathrm{mmol} / \mathrm{l})$ & 143 & $(138-145)$ \\
\hline $\mathrm{K}(\mathrm{mmol} / \mathrm{l})$ & 4.2 & $(3.6-4.8)$ \\
\hline $\mathrm{Cl}(\mathrm{mmol} / \mathrm{l})$ & 110 & $(101-108)$ \\
\hline Corrected calcium (mg/dl) & 10.23 & $(8.8-10.1)$ \\
\hline Phosphate (mg/dl) & 3.08 & $(2.7-4.6)$ \\
\hline Uric acid (mg/dl) & 8.48 & $(3.7-7.0)$ \\
\hline Plasma glucose (mg/dl) & 105 & $(73-109)$ \\
\hline Hemoglobin A1c (NGSP) (\%) & 5.8 & $(4.9-6.0)$ \\
\hline LDL-cholesterol (mg/dl) & 303.2 & $(65-139)$ \\
\hline HDL-cholesterol (mg/dl) & 81.3 & $(40-90)$ \\
\hline Triglycerides (mg/dl) & 146 & $(40-149)$ \\
\hline C-reactive protein (mg/dl) & 0.16 & $(<0.14)$ \\
\hline Immunoglobulin A (mg/dl) & 308 & $(93-393)$ \\
\hline Immunoglobulin M (mg/dl) & 84 & $(33-138)$ \\
\hline Immunoglobulin G (mg/dl) & 827 & $(861-1747)$ \\
\hline
\end{tabular}

Table 1 Laboratory characteristics of the patient (Continued)

\begin{tabular}{lll}
\hline Valuables & \multicolumn{2}{l}{ (normal range) } \\
\hline C3 $(\mathrm{mg} / \mathrm{dl})$ & 131 & $(73-138)$ \\
C4 $(\mathrm{mg} / \mathrm{dl})$ & 46 & $(11-31)$ \\
Anti nuclear antigen & Negative & \\
HBs-Ag & Negative & \\
HCV-Ab & Negative & \\
a-gal activity in WBC (nmol/h/mg protein) & 1 & $(20-80)$ \\
Plasma Lyso-GB-3 (nmol/l) & 7.4 & $(0.14-0.75)$
\end{tabular}

eGFR was calculated using the CKD-EPI equation

UPCR urinary protein/creatinine ratio, WBC white blood cells, $A S T$ aspartate aminotransferase, ALT alanine aminotransferase, eGFR estimated glomerular filtration rate, Na sodium, $K$ potassium, $C l$ chloride, $L D L$ low-density lipoprotein, $H D L$ high-density lipoprotein, $H B s-A g$ hepatitis B virus surface antigen, $H C V-A b$ hepatitis $C$ virus antibody, $a$-gal alpha-galactosidase, Lyso-GB-3 globotriaosylsphingosine

abnormalities could be related to proteinuria and renal dysfunction in patients with FD. Indeed, increased levels of proinflammatory cytokines and oxidative stress have been reported in patients with FD, who were treated with ERT [16]. Francesco et al. reported that the proinflammatory state involves two key subsets of innate immunity and provided direct evidence of GB-3 playing a proinflammatory role, likely mediated by Toll-like receptor-4 [17] Furthermore, compared with healthy controls, induced pluripotent stem cells from peripheral blood cell-derived endothelial cells in FD showed considerably increased reactive oxygen species (ROS) production [18]. In addition, the excess accumulation of GB-3 suppressed superoxide dismutase 2 expression and increased ROS production, finally causing vascular endothelial dysfunction in human umbilical vein endothelial cells [18]. Because prednisolone improves puromycin aminonucleoside-induced podocyte damage through the inhibition of mitochondrial dysfunction and ROS generation [19], the FD-associated massive proteinuria in our case may be improved by steroid therapy through inhibiting the dysregulation of ROS generation induced by GB-3. Moreover, the beneficial effect of calcineurin inhibitors on proteinuria is not dependent on the inhibition of nuclear factor activation in $\mathrm{T}$ cells but rather results from stabilization of the actin cytoskeleton in kidney podocytes [20]. Therefore, the mechanism of proteinuria normalization with a calcineurin inhibitor in this patient might be explained at least in part by stabilization of the actin cytoskeleton in podocytes. Further clinical and basic research is necessary to clarify this issue.

Although repeat renal biopsy is not available, biopsy findings on EM before and after immunosuppressive therapy and ERT would be of interest. All EM specimens showed foot process effacement, suggesting podocyte injury in this patient. It has been reported that podocyte foot process effacement is an early sign of FD without proteinuria or a decreased GFR [21]. It is speculated that 

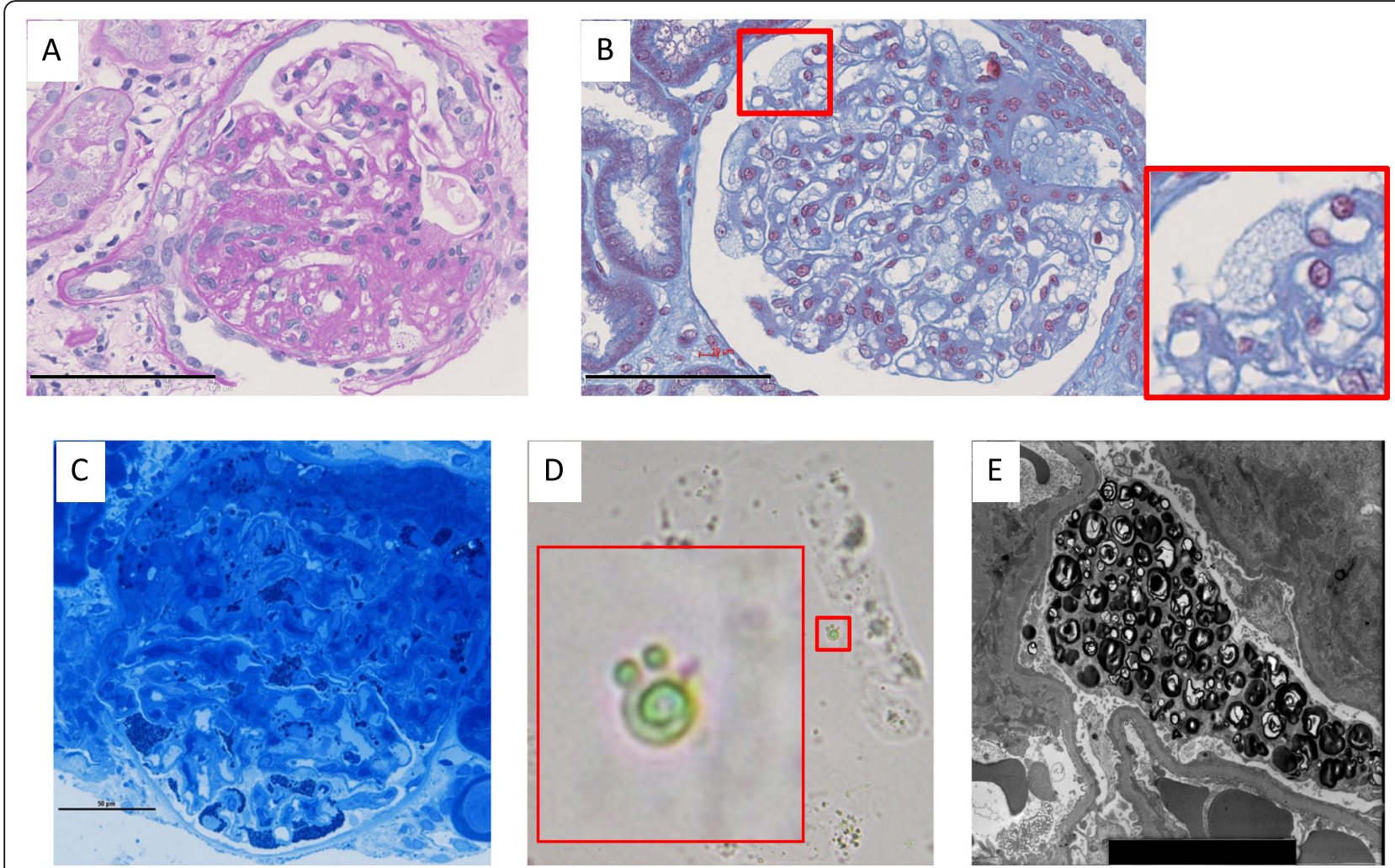

Fig. 1 Representative images of the renal pathology in the patient. a Fifteen glomeruli were collected, and one showed segmental sclerosis visible on hematoxylin and eosin staining (magnification $\times 400$, scale bar indicates $100 \mu \mathrm{m}$ ). b Masson trichrome staining showed vacuolization in podocytes (magnification $\times 400$, scale bar indicates $100 \mu \mathrm{m}$ ). c Toluidine blue staining revealed inclusion bodies in podocytes (magnification $\times 400$, scale bar indicates $50 \mu \mathrm{m}$ ). d Mulberry corpuscles were also found in the urine sediment. e Lamellar bodies in podocytes were observed by electron microscopy

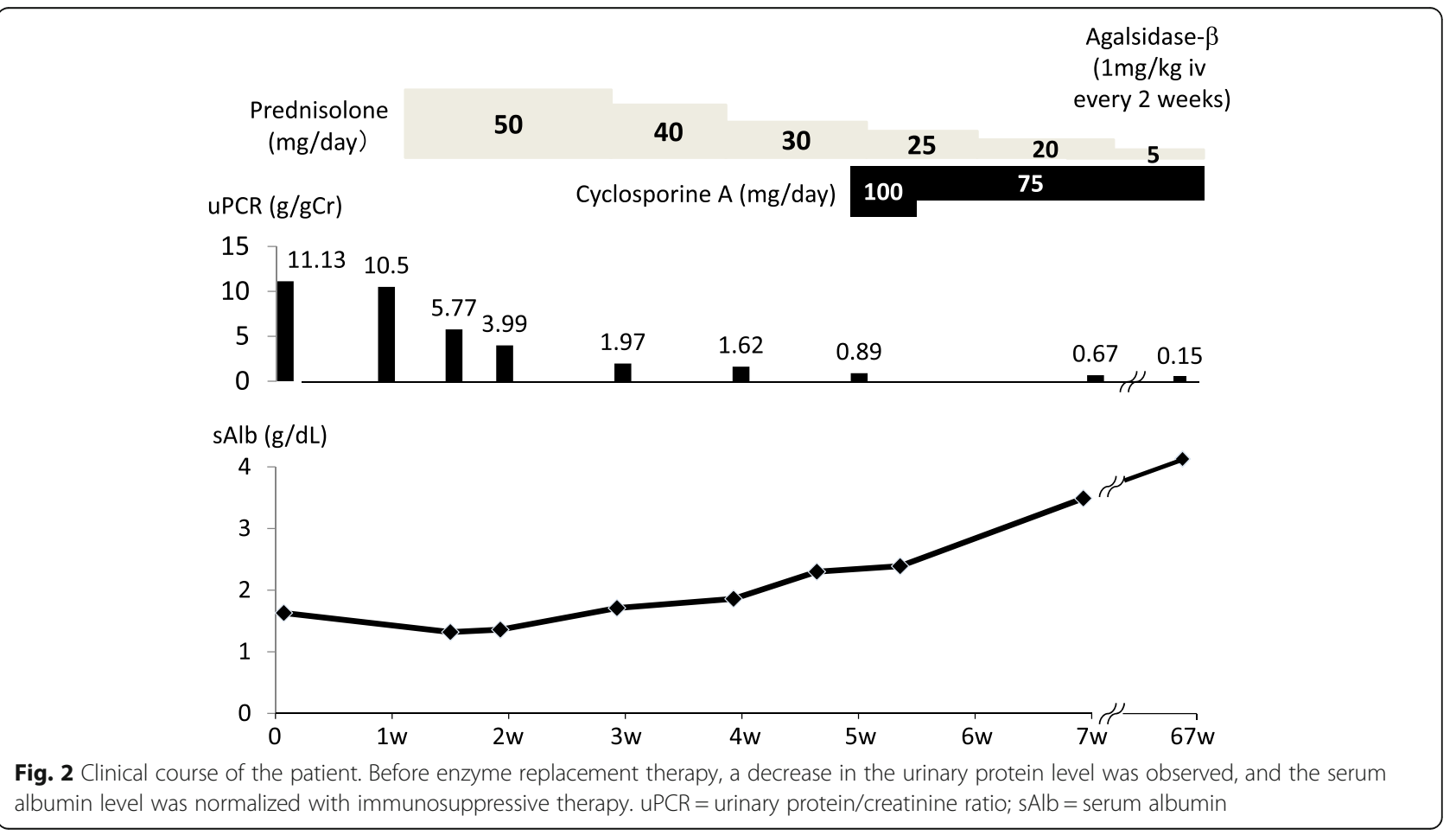


Fujisawa et al. BMC Nephrology

(2019) 20:469

Page 5 of 8

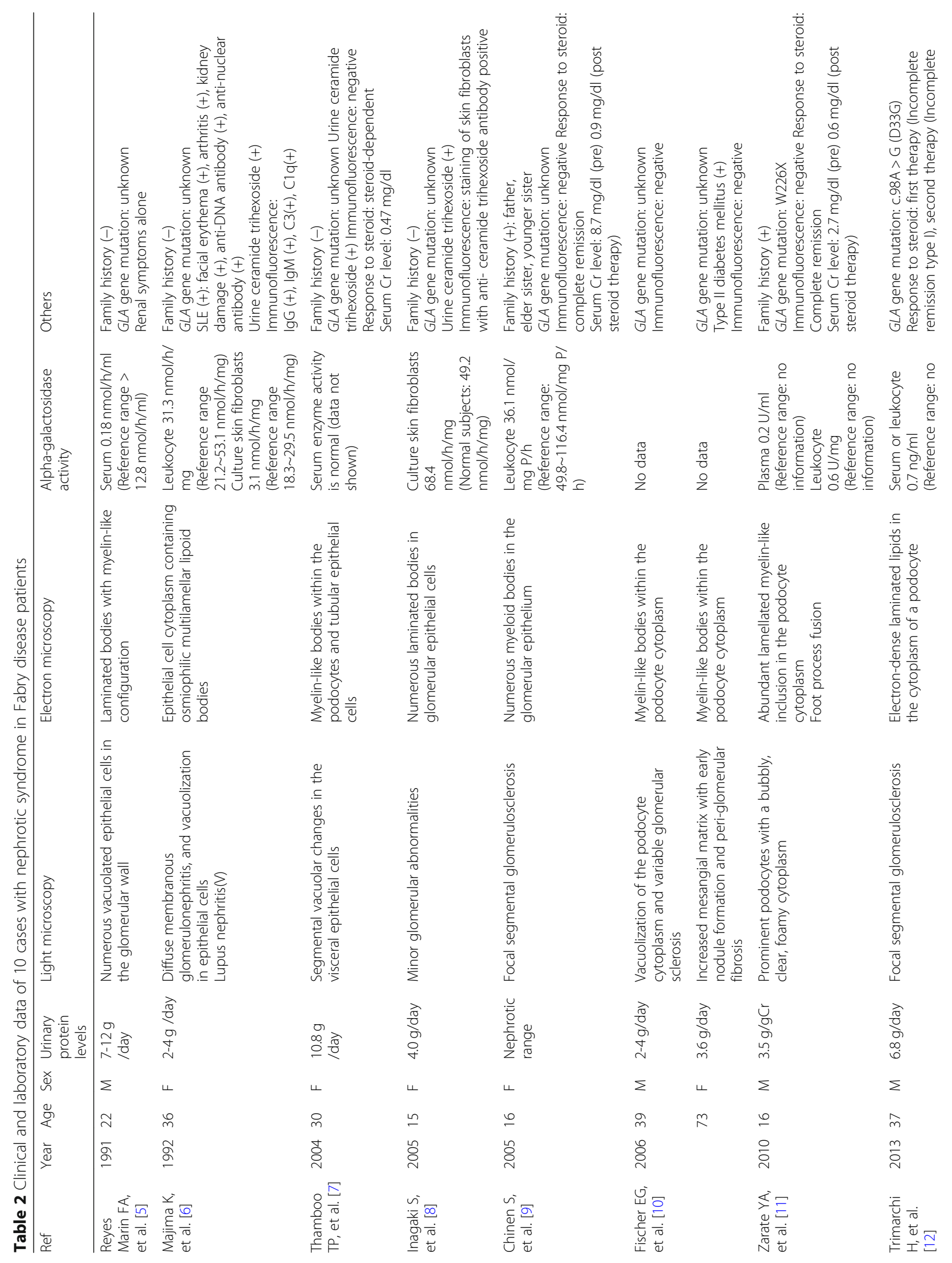


$\begin{array}{ll}\text { Fujisawa et al. BMC Nephrology } & \text { (2019) 20:469 }\end{array}$

Page 6 of 8

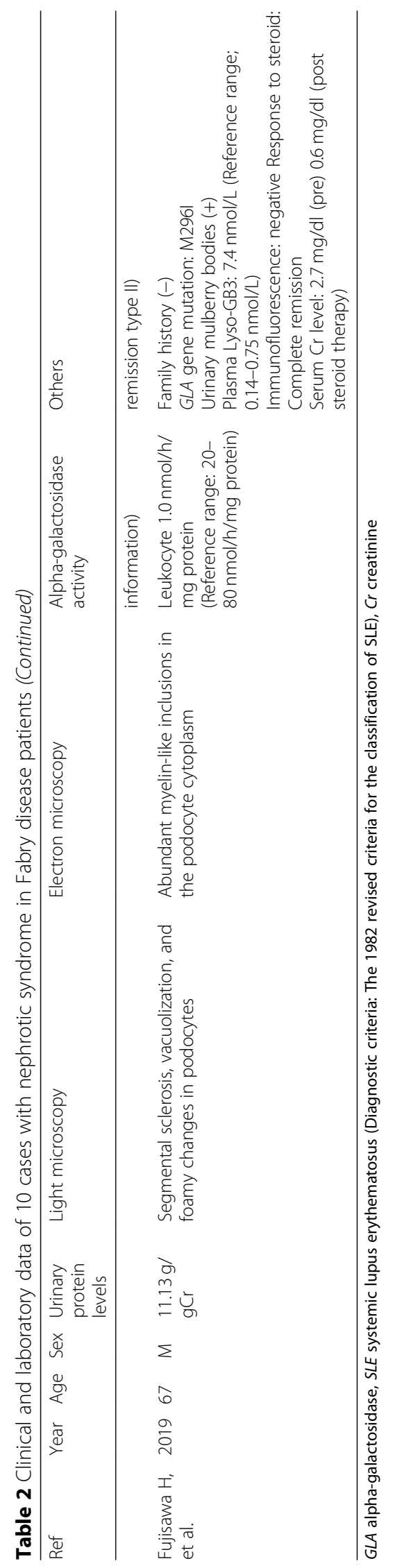


foot process effacement might be recovered and lamellar bodies in podocytes might be reduced by the immunosuppressive therapy in association with the reduced proteinuria in this case.

In this case, we detected mulberry bodies in the urine. Recently, mulberry bodies and cells have become useful noninvasive diagnostic markers in patients with lateonset FD, even in those with normoalbuminuria and/or normal renal function [22]. The source of mulberry bodies is believed to be podocytes and/or distal tubular epithelial cells. Since many podocytes detach from the glomerular basement membrane in late-stage FD, mulberry bodies can easily be detected in the early stage of $\mathrm{FD}$, as in this case.

This is the rare case of a patient with FD and nephrotic syndrome. Before FD was diagnosed, the patient's urinary protein level had dramatically increased to the nephrotic range but was normalized with immunosuppressive therapy. Nephrotic syndrome is unusual in patients with FD, and few cases have been reported [5-12] (Table 2). One patient was diagnosed with FD before renal biopsy [11], whereas the others were diagnosed with FD after renal biopsy. All patients exhibited the accumulation of glycosphingolipids in the glomerular epithelial cells on renal biopsy with or without typical findings of other nephropathy. Five patients including our case received steroid therapy and 4 patients achieved complete recovery from nephrotic syndrome $[7,9,11]$. A good response to steroid therapy is atypical in FD patients with heavy proteinuria. Three nephrotic patients including our case developed renal dysfunction, which was completely improved by the immunosuppressive therapy $[9,11]$. Therefore, if nephrotic-range proteinuria continues and develops, the coexistence of other nephropathies should be considered. In this regard, immunotherapy might be recommended in addition to ERT in nephrotic syndrome patients diagnosed with FD on renal biopsy.

\section{Abbreviations}

CyA: Cyclosporine A; ERT: Enzyme replacement therapy; FD: Fabry disease; FSGS: Focal segmental glomerulosclerosis; GB-3: Globotriaosylceramide; GLA gene: a-galactosidase A gene; ROS: Reactive oxygen species; WBC: White blood cell; a-gal activity: a-galactosidase A activity

\section{Acknowledgments}

We would like to thank Miss Shinkai for her excellent staining of the renal specimens.

\section{Authors' contributions}

All authors have read and approved the manuscript in its current state. HF, RY and YN treated the patient. SN provided his knowledge and ideas about Fabry disease. YK, NN, and AN diagnosed Fabry disease from the renal biopsy specimen. TTogawa, TTsukimura, and HS measured GAL activity and analyzed gene mutations. KF performed work related to the manuscript.

\section{Funding}

There was no funding support for this case report.
Availability of data and materials

The data that support the findings of this case report are available from KF (corresponding author).

\section{Ethics approval and consent to participate}

This research was approved by the Ethical Committee of Kurume University, Fukuoka, Japan (protocol identification number: 2018018). All procedures performed in this study involving this participant were in accordance with the ethical standards of the institutional and national research committee at which the study was conducted and with the 1964 Helsinki declaration and its later amendments or comparable ethical standards.

\section{Consent for publication}

Written informed consent was obtained from the patient for the publication of this case report and any accompanying images. A copy of the written consent is available for review by the editor of this journal.

\section{Competing interests}

KF has received personal fees from Sumitomo Dainippon Pharma Co., Ltd., outside of the submitted work. HS has received personal fees and research funding from Sumitomo Dainippon Pharma Co., Ltd., and Sanofi Japan Co. $\Pi^{1}$ corresponding to Tadayasu Togawa has received grants from Sanofi Japan Co., outside of the submitted work.

\section{Author details}

'Division of Nephrology, Department of Medicine, Kurume University School of Medicine, 67 Asahi-machi, Kurume city, Fukuoka, Japan. ${ }^{2}$ Kirishima Kinen Hospital, Kagoshima, Japan. ${ }^{3}$ Department of Functional Bioanalysis, Meiji Pharmaceutical University, Tokyo, Japan. ${ }^{4}$ Department of Clinical Genetics, Meiji Pharmaceutical University, Tokyo, Japan.

Received: 23 August 2019 Accepted: 3 December 2019

Published online: 17 December 2019

\section{References}

1. Breunig F, Weidemann F, Beer M, Eggert A, Krane V, Spindler M, Sandstede J, Strotmann J, Wanner C. Fabry disease: diagnosis and treatment. Kidney Int Suppl. 2003;84:S181-5.

2. Møller AT, Jensen TS. Neurological manifestations in Fabry's disease. Nat Clin Pract Neurol. 2007;3(2):95-106.

3. Nakao S, Takenaka T, Maeda M, Kodama C, Tanaka A, Tahara M, Yoshida A, Kuriyama M, Hayashibe H, Sakuraba H. An atypical variant of Fabry's disease in men with left ventricular hypertrophy. N Engl J Med. 1995;333(5):288-93.

4. Ortiz A, Oliveira JP, Waldek S, Warnock DG, Cianciaruso B, Wanner C, Registry F. Nephropathy in males and females with Fabry disease: crosssectional description of patients before treatment with enzyme replacement therapy. Nephrol Dial Transplant. 2008;23(5):1600-7.

5. Reyes Marín FA, Gómez Navarro B, Tamayo y Orozco J, Larriva Sahd J, Hernández Pando R, Velázquez Forero F, Peña JC. Nephropathy in a case of Fabry's disease. Rev Investig Clin. 1991:43(4):373-6.

6. Majima K, Ishizaki T, Inoue T, Hori Y, Egami J, Oohara A, Nishida H, Miyake Y, Matsumoto S, Kinoshita E. A case of Fabry's disease associated with lupus nephritis. Nihon Jinzo Gakkai Shi. 1992;34(11):1189-94.

7. Thamboo TP, Sivaraman P, Chan NH. Pathologic quiz case: an unsuspected cause of nephrotic syndrome. Heterozygous Fabry disease. Arch Pathol Lab Med. 2004;128(5):593-4.

8. Inagaki S, Migita M, Hayakawa M, Fujita A, Yoshida J, Ishizaki M, Kotani M, Sakuraba H, Shimada T, Murakami M, et al. An asymptomatic heterozygous female with fabry disease: implications for enzyme replacement therapy. J Nippon Med Sch. 2005;72(6):387-90.

9. Chinen S, Tana T, Kohagura K, Yamazato M, Iseki K, Takishita S. Two unusual cases of Anderson-Fabry disease in a Japanese family. Clin Nephrol. 2005; 63(5):390-3.

10. Fischer EG, Moore MJ, Lager DJ. Fabry disease: a morphologic study of 11 cases. Mod Pathol. 2006;19(10):1295-301.

11. Zarate YA, Patterson L, Yin $\mathrm{H}$, Hopkin RJ. A case of minimal change disease in a Fabry patient. Pediatr Nephrol. 2010;25(3):553-6.

12. Trimarchi H, Karl A, Raña MS, Forrester M, Pomeranz V, Lombi F, lotti A. Initially nondiagnosed Fabry's disease when electron microscopy is lacking: the continuing story of focal and segmental glomerulosclerosis. Case Rep Nephrol Urol. 2013;3(1):51-7. 
13. Maixnerová $D$, Tesař $V$, Ryšavá $R$, Reiterová J, Poupětová $H$, Dvoráková $L$, Goláň L, Neprašová M, Kidorová J, Merta M, et al. The coincidence of IgA nephropathy and Fabry disease. BMC Nephrol. 2013;14:6.

14. Liu Y, Xie H, Lin H, Chen S, Wang W, Zhao G, Zhang X. Coexistence of Fabry disease and membranous nephropathy. Iran J Kidney Dis. 2016;10(1):48-50.

15. Hanaoka H, Hashiguchi A, Konishi K, Ishii T, Kuwana M. A rare association between Fabry's disease and granulomatosis with polyangiitis: a potential pathogenic link. BMC Nephrol. 2014;15:157.

16. Biancini GB, Vanzin CS, Rodrigues DB, Deon M, Ribas GS, Barschak AG, Manfredini V, Netto CB, Jardim LB, Giugliani R, et al. Globotriaosylceramide is correlated with oxidative stress and inflammation in Fabry patients treated with enzyme replacement therapy. Biochim Biophys Acta. 2012;1822(2):226-32.

17. De Francesco PN, Mucci JM, Ceci R, Fossati CA, Rozenfeld PA. Fabry disease peripheral blood immune cells release inflammatory cytokines: role of globotriaosylceramide. Mol Genet Metab. 2013;109(1):93-9.

18. Tseng WL, Chou SJ, Chiang HC, Wang ML, Chien CS, Chen KH, Leu HB, Wang CY, Chang YL, Liu YY, et al. Imbalanced production of reactive oxygen species and mitochondrial antioxidant SOD2 in Fabry diseasespecific human induced pluripotent stem cell-differentiated vascular endothelial cells. Cell Transplant. 2017;26(3):513-27.

19. Yu L, Liu Y, Wu Y, Liu Q, Feng J, Gu X, Xiong Y, Fan Q, Ye J. Smad3/Nox4mediated mitochondrial dysfunction plays a crucial role in puromycin aminonucleoside-induced podocyte damage. Cell Signal. 2014;26(12):2979-91.

20. Faul C, Donnelly M, Merscher-Gomez S, Chang YH, Franz S, Delfgaauw J, Chang JM, Choi HY, Campbell KN, Kim K, et al. The actin cytoskeleton of kidney podocytes is a direct target of the antiproteinuric effect of cyclosporine A. Nat Med. 2008;14(9):931-8.

21. Tøndel C, Kanai T, Larsen KK, Ito S, Politei JM, Warnock DG, Svarstad E. Foot process effacement is an early marker of nephropathy in young classic Fabry patients without albuminuria. Nephron. 2015;129(1):16-21.

22. Shimohata H, Maruyama H, Miyamoto Y, Takayasu M, Hirayama K, Kobayashi M. Urinary mulberry cells and mulberry bodies are useful tool to detect lateonset Fabry disease. CEN Case Rep. 2017;6(2):148-51.

\section{Publisher's Note}

Springer Nature remains neutral with regard to jurisdictional claims in published maps and institutional affiliations.

Ready to submit your research? Choose BMC and benefit from:

- fast, convenient online submission

- thorough peer review by experienced researchers in your field

- rapid publication on acceptance

- support for research data, including large and complex data types

- gold Open Access which fosters wider collaboration and increased citations

- maximum visibility for your research: over $100 \mathrm{M}$ website views per year

At $\mathrm{BMC}$, research is always in progress.

Learn more biomedcentral.com/submissions 